\title{
SKILLS FOR CREATING SUPPORTIVE LEARNING ENVIRONMENTS - AN ESSENTIAL COMPONENT OF TEACHERS`PROFESSIONAL COMPETENCE
}

\author{
Kristi Kiilu \\ Estonian Academy of Music and Theatre, Tallinn, Estonia \\ Urve Läänemets \\ Estonian Academy of Music and Theatre, Tallinn, Estonia \\ Katrin Kalamees-Ruubel \\ Estonian Academy of Music and Theatre, Tallinn, Estonia
}

\begin{abstract}
The current research on music teachers' professional skills of structuring and developing supportive learning environments for implementation of National Curricula is the third in line, based on a pilot project of 2013, a study of 2015. The research problem for all the three studies was "How do music teachers at general comprehensive schools comprehend supportive learning environment and opportunities for their design and development. The data collected and analysed $(n=70)$ in 2019 allow to follow the development of teachers' professional abilities and creativity at structuring and designing supportive environments for learning music at general comprehensive schools and kindergartens. If smartly designed and created, they promote learning, lead to higher academic achievement and contribute to students' self-esteem. The study has also provided information about teachers' professional approaches, real environments at schools and the needs for improvement. The analysis of the data, providing some insights allows to make recommendations for teacher training, for curriculum design at school level and offer suggestions for cultural activities in local communities supporting cohesion and identity building in society. Current turbulent times require increasingly wider competences and creativity from teachers for making music education socially meaningful.
\end{abstract}

Keywords: creativity, music education, professional skills, social impact of music education, supportive learning environments, teachers' comprehension of environment structures.

\section{Introduction}

Whatever the curriculum says, teachers are the ones to implement it and responsible for their students' achievement (from a practicing teacher).

The issue of developing supportive learning environments (SLE) has been an issue for educational reforms related to implementation of new national curricula (NC) in all countries, also in Estonia where curriculum development for general comprehensive schools has been a difficult and often controversial 
process since regained statehood in 1991. The life span of educational aims, the selected content of learning as well as its organization usually does not exceed a decade, as the rapidly changing world around us with its new challenges sets new demands for education, especially to that meant for all the population. No curriculum reform can change everything overnight, however, new school subjects can appear and some disappear according to what is considered necessary and useful to know preparing the new generation for future life by answering the perennial question "What is worth learning?" Even if that has been specified in NC by careful selection, its implementation requires conditions needed for specific learning activities. These conditions can be defined by a common concept of learning environments, which can be characterised as educational approaches, cultural contexts or physical settings. Good learning environments these days are expected to be not only supportive, but also interactive and engaging, developing independent and critical thinking, and hopefully, leading to desired learning outcomes. The role and potential of supportive learning environments was also the key theme on the British Educational Training and Technology Show (January 2020), where 600 companies offered their educational products, which could be used to enhance learning of any kind (BETT, 2020). There is even a journal Learning Environments Research (LER) since 1998 and there are numerous articles, how to create context based learning environments in science subjects. There have also been advances in research concerning learning environments of different kind (e.g. Aldridge \& Frazer, 2008), the most recent one being an overview of thirty recent years (Zandvliet \& Frazer, 2019).

Although research on learning environments can be traced back for some forty years, there has been no research so far, how to create supportive learning environments for music education at general comprehensive schools. This article is dedicated to research in that particular field and how teachers could professionally design it.

\section{NC, music education and specific environments for that}

In additional to traditional languages, math, sciences and history, Estonian NCs of different times have always contained music as a compulsory school subject. It has often been questioned whether it really needs to be there, considering how long it takes to train music teachers, how costly it is to provide instruments, and accept the fact that not all people are musically talented. Accordingly, many, and not only politicians, have considered compulsory music education a waste of resources (money, time, competence). However, recent brain research has proved the value and meaning of music and musicking (a term meaning making music) for all people, as during developmental stages, active engagement with music can impact the way that the brain can process information, 
enhance the perception of language and speech, and subsequently improve our ability to communicate with others and learn to read (e.g. Hallam, 2010, et al.). So we have found new and solid arguments to proceed with music education with its full cycle from kindergarten up to the end of gymnasia/high schools.

The NC of 1996, 2002 and 2010/2011 have specified rather high aims. The NC of 2011 lists development of students' musical literacy skills, /.../ comprehension and respect different national cultures /.../, creation of pieces of music /... with the following components: singing, playing musical instruments, musical movement, composing, listening to music and musicology, musical literacy and educational outings /.... By introducing Estonian and global music culture to the students, their musical tastes and socio-cultural value judgements are shaped. (NC, 2011)

All these undoubtedly positive cultural and social aspirations specified as aims need to be described as a carefully selected content for learning, and put into practice at school level. When the content of learning in syllabi has been described, conditions for acquisition of particular knowledge and skills have to be created. It means implementation of the NC by teachers, primarily creation of the learning process with its specific learning activities in suitable learning environments. Accordingly, all school subjects require specific environments. However, the NCs of 2010/2011 have for the very first time in music syllabi, both for compulsory schools and gymnasia us specified requirements for the physical environment for music education as follows.

The school enables the students to use the following resources: natural piano, and piano chair, synthesizer, audio system, board with staves, music stands, shifting quarter note, scale degrees`chart, keyboard chart, a computer with a sound card and Internet connection with notation and MIDI recording software. The school conducts the lessons in a classroom where students can work in groups and there is sufficient space for movement. The school provides the necessary instruments (the Orff-set of instruments, recorder or 6-string smaller zithers and acoustic guitars) for the students to engage in making music. (NC, 2011)

Our research was triggered by the fact that such a specification, although listing several objects, was unstructured and not systematic, which made practical implementation difficult, because meaningful and needed environments to support teaching and learning music are much more diverse. Music teachers as well as other subject teachers have to consider many more opportunities for creating their subject specific SLEs and have the skill to structure and develop them into a practically functioning system. The pilot studies of 2013 and 2015 showed already then that environments for music education were considerably more advanced than described in the NC as the majority of schools had special choir classes (to preserve our tradition of Song Celebrations). These 
have usually adjacent front tables and seats, placed on different levels of semicircular steps, so that all singers can see the conductor and be organized by vocal groups when performing music (Laanemets \& Rostovtseva, 2015).

This article is a summary of three different research projects of 2013, 2015 and 2019 showing the development of music teachers' comprehension, how to structure, design and create SLEs for music education, considering different opportunities of formal, informal and non-formal education.

\section{Theoretical background and components of learning environments}

We probably have to agree with Edmonds (Edmonds, 1999), who claimed already then all learning environments be complex and multidimensional, and even if its components were known, it is still not easy to unite it into a meaningful and systematic whole, most suitable for learning a particular subject, topic or skill. Kurt Lewin (1936) was among the first to discuss the concept of personenvironment fit (PEF) and simply said - by creating learning environments that align with the needs of learners, educators can maximize achievement of their students and themselves. Understandably, as learners vary, teachers must be able to create varied learning environments. At the same time, teachers have to consider the subject content they teach, so that they can recognise all possible opportunities that can be used for learning and understanding the meaning of knowledge and skills provided by a particular school subject. All educators should understand that the learner is at the heart of creating effective and varied learning environments, which enable students to understand, why a particular environment (technical, cultural, linguistic, etc.) is useful and supportive for their learning. It probably goes without saying that teachers should try to identify features of environments that help to create developmentally appropriate conditions, so that learners of all ages feel secure, comfortable, welcome and ready to explore and learn.

Wilson (1995) has specified minimal learning environments where there have to be learners and functional rooms/spaces used for studies. In 2006 Salomon (Salomon, 2006, 255) considered any environment suitable for learning, if specially designed and where learning takes place as a supervised process and where instruction can be provided by teachers, computers, worksheets, etc. Harsh and Young (2015) explain a strategic approach to designing such environments for maximum impact through deeper learning by using real world examples. Environment variations can be designed to enhance depth of content, augment instructional processes or expand the range of students' learning outputs. (Harsh \& Young, 2015, 79)

Although several researchers have tried to analyse and structure different environments in diverse way, it is really difficult to generalize, or even describe 
them adequately. Finnish specialists (Manninen et al., 2007, 36-41) have specified five of them: physical, social, technological, local and didactical environments, which allow to gain a broader view of available opportunities that could be used as environments for learning. It is also possible to consider formal, informal and non-formal educational spheres that could be used for acquisition of desired and intended knowledge and skills. In Estonian teachers' training, when talking about supportive learning environments, we usually specify three big fields: spatial conditions, study aids and social environments. (Läänemets, 2013/2017, 46-47).

Spatial environments have to be functional and provide the facilities required for specific learning activities. It starts with school architecture, e.g. classrooms, gyms, labs, etc. All infrastructure, including school territories must meet safety, hygiene and aesthetic standards.

Study materials have to correspond to the content of syllabi specified in the NC. In addition to traditional textbooks, workbooks, maps, instruments etc., there are numerous study aids available in virtual environments. However, traditional study aids probably stay for long. There is ample research to support the potential of different textbooks for learning. According to Ruuska (2015) a textbook is a framework that learning is based on (Ruuska, 2015, 43). Vuorinen (2015) considers all teaching materials tools that are adapted to the needs of the teacher and the pupils, enabling access to new information and learning new things (Vuorinen, 2015, 117). Moreover, Elomaa (2009) suggests that teachers might gladly use textbooks because they do not have the time themselves to prepare appropriate material for their students (Elomaa, 2009, 31). It has to be agreed that the textbook provides a good framework for teaching and leads the way in a sense, to which teachers can add other elements they see fitting. Guerretaz \& Johnston (2013) say that the textbook provides structure and even acts as the curriculum (Guerrettaz \& Johnston, 2013, 781). The fact that teachers more often teach the textbook than design a school curriculum for implementation of the NC seems to be true in many countries.

Social environments and organization of learning activities means school organization and management by a rational timetable and professional teamwork, providing friendly and supportive atmosphere and where individual abilities and capacities are respected. It also means potential support from school leaders to extracurricular activities, cooperation between school and homes. Meaningful integration of all potential and opportunities of formal, informal and non-formal education are much more important for music education than any other school subject (Läänemets et al., 2018).

It can be concluded that although some basic elements of SLE can be specified, its design remains subject specific and greatly dependent on teachers' professional skills and creativity. 


\section{Objectives, methods and data collection}

The objective of the studies was to observe and analyse how teachers' professional skills have developed and how environments, which music teachers can use, have developed and improved in the process of implementation of the music syllabus as specified in the most recent NC. Based on recommendations offered in the studies of 2013 and 2015 some changes were made in music teachers' pre- and in-service training at the Estonian Academy of Music and Theatre, which allowed to see the preliminary impact of the introduced changes.

The research questions were the following:

1. How do teachers understand the concept of learning environments and how can they structure them?

2. What are the materials/study aids they can use to develop supportive environments?

3. What has changed/improved in SLE for music education in recent years?

4. What are the teachers' present needs for creating supportive learning environments for motivating and successful music education?

Our three studies can be considered longitudinal in character, as they are descriptive and based on data collected over an extended period of time (from 2012-2019). Considering the fact that Estonian music teachers rarely change their jobs, mostly the same respondents were studied at different points in time, which makes the study also "cross-sectional". A cross-sectional study provides a „snapshot” of a population at a particular point in time (Cohen \& Manion, 1997, 68). For all three research projects, mixed methods were used as this type of research provides a more complete view, and it also helps during the different phases of a research project to choose the right and effective tool for the study. (Guest, 2013; Johnson \& Christiansen, 2014; Creamer, 2017 et al.)

The research data were collected by semi-structured questionnaires, both paper and web-based and by focus groups' interviews in 2013 and 2015. In 2019, web-based questionnaires and focus groups interviews were used. The questions were influenced by the theoretical framework to an extent, but the analysis is still more inclined to be data-driven (Vanha, 2017, 25). The data was analysed using content analysis method (Tuomi \& Sarajärvi, 2009), which describes the phenomenon - in this case learning environments for music education - and the purpose of the analysis is to create a verbal and clear account of it through text analysis. The purpose of the analysis of qualitative data is increasing the information value to create meaningful, clear and coherent information from disconnected data. (Vanha, 2017, 24)

Conclusions about the phenomenon being inspected can be used for making recommendations for organizing teacher pre-service and in-service training but 
also for curriculum development, implementation, especially for economics of education.

The final study was carried out in 2019. Since 2016/2017 the course theme of learning environments has been included into the pre- and in-service music teacher training curricula. The study of 2019 used a random sample of 70 respondents, all of which work as music teachers in towns (41\%) or rural schools (59\%). $48 \%$ of teachers have MA degree of a certified music teacher, the others have BA or have studied at vocational music school, some have attended in-service teacher training courses within "Open University" projects. All respondents were given a number for analysis. 55,8\% of respondents have been working longer than 15 years, 32,9\% have work experience of more than 20 years. $25,7 \%$ of respondents have worked 1 to 5years. Teachers' work load is rather big and they mainly work at one school: $34,2 \%$ of them delivers $21-29$ lessons per week, $15,7 \%$ have incredibly up to 30-37 weekly working hours. Their activities consist of music lessons (98,6\% of the work load), supervising and conducting choirs $(81,4 \%)$, orchestras $(5,7 \%)$, ensembles $(40 \%)$ or soloists $(2,9 \%)$.

\section{Results and discussion}

Results of the analysis are presented by the criteria as follows, which are based on research questions.

\section{How do teachers comprehend SLE and how do they structure it?}

Compared to earlier data, teachers have started to structure the SLE more precisely and they still start with spatial conditions where the music lessons take place. Whether the room is supportive or not for learning music, they usually do not specify or explain what the potential of a particular classroom is.

$79 \%$ of respondents use specially equipped music classrooms and they consider it also supportive for teachers, but they do not want to share it with teachers of other subjects. If they have to use ordinary classrooms, they have to use a different environment, not organized by themselves and it seems to disturb them. Perhaps it should also be studied, how different environments (specially designed SLE and ordinary rooms) impact on students' learning activities. 27,1\% of respondents carry out their music lessons in ordinary classrooms, $20 \%$ use school assembly hall and ordinary classrooms. However, it was not specified, whether they used the same room or was it a random choice according to the school lesson plan. In five cases music teacher use a computer class, lecture halls, corridors and even the balcony of the school assembly hall has once been mentioned. Understandably, in such cases we cannot talk about SLE, or teachers' preparatory attempts to structure and/or design environments specifically for their subject, although it would be critically needed. According to Meador (2019) in a structured learning environment, students are more likely to thrive and experience 
personal and academic growth. Too often teachers provide students with freedoms that they can abuse. A lack of structure can destroy a learning environment and undermine a teacher's authority, leading to misbehaviour and wasted time that could be used for learning. Thus, it has to be acknowledged that teachers cannot always use their existing skills to structure and design suitable and supportive learning environments.

It takes time to bring music instruments and study aids from one classroom to another, as the only available time for that are breaks between lessons. Teachers consider it unnecessary, tiring and often causing stress, sometimes even unmanageable. (R20) It also became clear that in schools, where music lessons take place at ordinary or at random chosen places, the school leaders' supportive role to music activities at school have not been mentioned.

Structuring of SLE and choice of classrooms also greatly depends on the number of students in a class, for whom the music lesson is delivered. Music lessons are usually organized for the whole class at all school levels: $41,4 \%$ of respondents reported the class size of $21-25$ students, $34,2 \%$ more than 25 students.

\section{What kind of study aids are available for creating SLE for music education?}

All respondents have learned to differentiate between diverse study aids, and even in some cases, characterize shortly their potential which was not there in teachers' answers in 2013. They usually list textbooks and workbooks for music education, but also music instruments.

There are no clear preferences between materials offered by different publishing houses, usually teachers have their own individual taste, sometimes based on repertoire of songs offered, etc. Teachers are reasonably well informed about the study aids and materials available, but they mostly use textbooks they have got used to during several years of their school practice. About $20 \%$ of respondents say that buying new textbooks or other materials for music education is not the priority at their schools. $70 \%$ of the teachers questioned are using textbooks, but $12,4 \%$ does not. In $80 \%$ of all cases all students have got their individual school music textbook. Teachers often claim that textbooks are meant and mainly to be used in lessons. So every child really has his/her own textbook (there is usually one set of class textbooks, which can be used in different classes). (R 38)

When comparing the use of textbooks and workbooks, teachers clearly prefer textbooks. This is usually explained by the fact that they have to follow the requirements of the music syllabus in the NC. Still, teachers often do not comprehend neither the role of the workbook as a part of the full set, designed by textbook authors, nor the full potential and functions of workbooks in general. However, workbooks can be a useful tool for teachers and offer a number of 
diverse, interesting and meaningful learning activities, which in turn, greatly contribute to SLE, and provide opportunities for differentiated learning.

However, 38,6\% of respondents claim workbooks necessary, 6\% considers them most necessary (usually teachers working with a big work load). It is good for consolidating acquired knowledge. A good tool for revising the themes already covered. Helps to development of literacy and notation, etc. (R 24) Workbooks make lessons more flexible and they offer students tasks good for development of their theoretical skills in music. (R 28) It is not possible for teachers constantly compile new tasks and/or exercises. Workbooks contain so many smart and practical consolidating exercises. (R69) It is quite simple for children to find and understand instructions for exercises and finish them at home. It also helps to catch up with learning, if they have been absent from school. (R 19) Children like workbooks, and they make teachers work less time consuming, especially for those, working with a big load. (R 26)

When the school has managed to buy workbooks, so all students in the class have them (86\%). If only the teacher has bought it (11\%), he/she usually copies some exercises as worksheets, especially at gymnasium/high school level. I often use workbook exercises as basis and compile similar to them my own worksheets. (R 35)

$28 \%$ of respondents are of the opinion that workbooks are necessary in some cases only, (or at some school level). I usually have more practical music activities, and we study notation in the general process together with playing instruments, singing and their own compositions. (R 41) Most needed in grades 1-3. For comprehension, in grades 4-6. It is more interesting and meaningful to compile worksheets myself. (R 9) Workbooks could be at school available from grade 7 onwards, (just one class set), so that students could do some of these exercises now and then by copying them into their ordinary exercise books. (R 60)

$14,3 \%$ of respondents consider workbooks not particularly necessary. There are lots of senseless exercises for me in textbooks. (R 4) Students' learning should focus on practical activities, not writing. (R 70) I believe every teacher should have their own style, how to plan music lessons. It should depend on an individual teacher personality. If necessary, I can compile all worksheets myself and there are lots of good materials in the Internet. (R 22) The majority of tasks in workbooks are of very little use. It is not rational to buy a full set of workbooks for a few good exercises. (R 42) Not necessary at all. We use ordinary exercise books and music sheets. (R 32)

The opinions presented above may mean freedom for some teachers to decide about everything themselves and make them absolutely convinced about ones' high professionalism (compile worksheets, etc. themselves) or "specific style". It also has to be mentioned, that those teachers, not using textbooks or workbooks $(14,3 \%)$ have acquired their qualification quite recently (during the 
last decade, mostly by attending courses, and they have been working at school for a few years only. Perhaps some of these have tried to follow the so-called "new approach to learning”, where freedoms of different kind have been highlighted, both for students and teachers.

However, if schools want to follow well organized activities leading to attainment of aims set, such approaches with irregular activities without meaningful SLE may lead to ineffective learning processes, depriving students of opportunities to train their skills, especially new techniques. It can become rather difficult for inexperienced teachers, and they can lose boarders between sequenced topics/units for studies and make students feel incapable of learning music. It is still important to highlight the fact that such a considerable number of respondents do not consider study aids as a part of SLE. It still has to be stressed that „textbooks assist managing a lesson, it saves time, give direction to lessons, guide discussion, facilitate in giving homework, making teaching 'easier, better organized, more convenient', and most of all, it provides confidence and security.” (DBE, 2015)

All music teachers consider music instruments important for SLE, more specifically in the lessons they deliver. There are usually pianos of different kind at schools (98,6\%), rhythmic instruments $(92,9 \%)$, barred instruments $(80 \%)$, small cithers (65,7\%), guitars (54,3\%), drum sets (40\%), ukuleles (21,4\%). In addition to those teachers also use their own individual instruments: flutes, violins, double bass, accordions, guitars, etc. I keep them in my music class and use as a study aid. (R25)

\section{What do teachers still need for development of SLE?}

Usually teacher want to have more different music instruments (51\%), technical equipment of good quality stationary music class with movable furniture (for making space for movement). In addition to those they mention that in-service training courses organized by different institutions/entrepreneurs are few, they are often of low quality and unsystematic. In recent times we also have to use different digitalized study aids, there are usually some general courses available. However, there is practically nothing for development of specific musical skills for listening, guessing various games, which we really need. (R 11) Teachers want trainings/courses in smaller groups, because in big groups practical music activities and use of instruments remains insufficient. (R 44) They also expect greater interest in music from children. It is inevitable for younger teachers to face the fact that senior students have not been taught by me and they have not learnt to love and value music. I am trying to develop that love among younger children, but for the senior students it is unfortunately too late already. (R 63) Some respondents also say that students do not always take learning music with responsibility as students think that they come into the music lesson to sing and have a rest. ( $\mathrm{R} 28$ ) There is a widely spread understanding in society that music 
is just entertainment. However, the job of a music teacher is one of the toughest at school, and only the other music teacher can understand it, nobody else. (R 41) I understand that it is the task of music education to develop interest in music, but when they experience success, when performing, it could lead them to continue with making music in their later life. This would probably improve mental health in all society and make it less money-oriented. Unfortunately, many music teachers choose a simpler route and focus on music history in their lessons. Still, it can be delivered in a most fascinating way, and there could be most intriguing tasks for listening and song repertoire related to that, which also can be most developing for all people. I believe many music teachers consider them bad teachers, because they do not have enough time for their musical activities (especially playing instruments) and there are not enough resources at schools to organize music activities. (R 5)

4. How have teachers' professional skills to structure and create SLE developed at schools and outside schools?

As before, according to studies of 2013 and 2015, everything depends on the work load of music teachers. They work with choirs, ensembles, orchestras and soloists, which means that they have to create different SLE considering the students they work with and activities they have to organise, as the aims of musical activities are different. In addition to delivering music lessons there are lots of traditional activities and events at school music teachers are made responsible for, as their students are expected to perform there: festive events, graduation ceremonies, school anniversaries, Christmas and spring concerts, mothers' and fathers' days, teachers' day, the first school day event in September, etc.

In addition, there are church concerts, advent concerts, concerts for young musicians, competitions for ensembles, orchestras, soloists, etc., family days, festivals, events for young composers, choir camps for exercising for traditional Song Celebrations everybody is eager to take part in at least once in a life-time. This list tells about active music life in Estonia, but it also means additional work for music teachers.

For making music education more diverse and offer student experience of listening professionally made music, schools widely use concerts, organized by the company Eesti Kontsert. It is possible to book shorter school concerts, but also full performances. (R 16) These events are mainly offering classical music and these are the concerts students perhaps would not go on their own initiative. (R 58) Needless to say, experience with high quality professional music „can improve learning and increase positive classroom atmosphere”. (Eerola \& Eerola, 2013) Teachers have also mentioned professional musicians and composers, former graduates of their schools, who willingly come to concerts and other events. Understandably, this is not the case with all schools. 
$78,6 \%$ of respondents said that they often perform in their community, especially from small schools of rural areas. 59\% of respondents reported performing in events in Tallinn and other towns. Teachers also mentioned their students' participation in competitions $(45,7 \%)$, festivals $(31,4 \%)$, concert tours $(12,9 \%)$.

Music teachers also feel the support of local music schools (40\%) and hobby groups (37,3\%), although no active cooperation has been mentioned. Some teachers do not know, how many of their students attend music schools. However, some say that there is too little support, as it is extremely difficult to find people to teach playing instruments or dancing. (R 34) Understandably, those students attending music schools, perform more often at school events. Unfortunately, 8\% of respondents claim that they are not supported in any way in their community.

All music education at schools is closest connected with the Estonian cultural great event - Song Celebrations. To have the right and take part in this event is the aim of all choirs. $67,1 \%$ of respondents have been singing there more than once, $10 \%$ once, but $22,9 \%$ of respondents have never taken part in these celebration with any of their school choirs. Sometimes they still perform at local Song Celebrations which take place more often. Choirs of those music teachers, who have worked at school 20 or more years, have also attended Song Celebrations more often. Two respondents explained their no-attendance with the fact that they have worked at school only 1 year. Six respondents admitted the fact that they had not passed the compulsory rehearsal.

It can be concluded that the majority of music teachers are active in creating both at school and outside school SLEs, but there is still a long way to go for using all the potential for its enrichment.

\section{Conclusion and recommendations}

Although the data collected over a period of 8 years was not too long, it can be considered adequate for monitoring, how the music syllabus in the NC was implemented. It can also be concluded that music teachers' professional understanding and thinking have improved in time, especially after the topic on design and creation of supportive learning environments was included into their pre- and in-service training. They have learnt, how important SLEs are and what the potential of meaningful integration of diverse opportunities of formal, informal and non-formal education could be for development of successful music education. Their skills for structuring and designing SLE have also developed, which has contributed to their professional abilities. However, it has to be admitted that music teachers work under rather different conditions, which cannot always be considered as SLE for music education at schools only. Accordingly, both school environments as well as activities and events out-of school need 
systematic monitoring. Still, it has to be stressed that more attention should be paid to SLE when training all teachers of all subjects. We have proposed a specialized course on theory and implementation of NC could be added to all teacher training programs, which undoubtedly could provide new professional knowledge and skills in their respective fields. Smart development of SLEs would make learning any school subject more successful and meaningful for students as well as for teachers' when planning and carrying out their work.

\section{References}

Aldridge, J.M., \& Frazer, B.J. (2008). Outcomes-Focused Learning Environments: Determinants and Effects. Rotterdam, The Netherlands: Sense Publishers.

Best, J.W. (1970). Research in Education. Prentice-Hall, Englewood Cliffs, New Jersey.

Cohen, L., \& Manion, L. (1997). Research Methods in Education. Fourth Edition. London: Routledge.

Creamer, E.G. (2017). An introduction to fully integrated mixed methods research. Thousand Oaks, CA: Sage.

Department of Basic Education. (2015). The effective use of textbooks in the classroom. The Ministry of Education of the Republic of South Africa. Retrieved from https://www.umalusi.org.za/docs/presentations/2015/textbooks.pdf

Eerola, P.S., \& Eerola, T. (2014). Extended music education enhances the quality of school life. Music Education Research, 16(1), 88-104.

Elomaa, E. (2009). Oppikirja eläköön! Teoreettisia ja käytännön näkökohtia kielten Oppimateriaalien uudistamiseen. Jyväskylä: Jyväskylä University Printing House.

Guerrettaz, A.M., \& Johnston, B. (2013). Materials in the classroom ecology. The Modern Language Journal, 97(3), 779-796. Retrieved from https://onlinelibrary.wiley.com/doi/ pdf/10.1111/j.1540-4781.2013.12027.x

Guest, G. (2013). Describing mixed methods research: An alternative to typologies. Journal of Mixed Methods Research, 7, 141-151. Retrieved from https://doi.org/10.1177/ 1558689812461179

Eesti Vabariigi valitsus. (2011). Gümnaasiumi riiklik õppekava (National Curriculum forupper secondary schools. In Estonian). Retrieved from https:/www.riigiteataja.ee/akt/ 129082014021

Eesti Vabariigi valitsus. (2011). Põhikooli riiklik õppekava (National curriculum for basic schools. In Estonian). Retrieved from https://www.riigiteataja.ee/akt/129082014020

Hall, R.A. (2015). Critical Thinking in Online Discussion Boards: Transforming an Anomaly. The Delta Kappa Gamma Bulletin, Spring 2015, 81-3, 21-28.

Hallam, S. (2010). The power of music: Its impact on the intellectual, social and personal development of children and young people. International Journal of Music Education, 28(3), 269-289. Retrieved from http://legacy.laphil.com/sites/default/files/media/pdfs/ shared/education/yola/susan-hallam-music-development_research.pdf

Harsh, S., \& Young, J. (2015). Using varied Learning Environments for Deeper Learning and Student Mastery of Complex Content. The Delta Kappa Gamma Bulletin, Spring 2015, $81-3,7-16$

Heller, D.E. (2001). The states and public higher education policy: Affordability, access and accountability. Baltimore, MD: Johns Hopkins University Press. 
Johnson, R.B., \& Christensen, L.B. (2014). Educational research: quantitative, qualitative, and mixed approaches (5th ed.). Los Angeles, CA: Sage.

Kubota, R., \& Austin, T. (2007). Critical approaches to world language education in the United States: An introduction. Critical Inquiry in Language Studies, 5(2 \& 3), 73-83.

Lewin, K. (1936). Principles of Topological Psychology. New York: McGraw-Hill.

Laanemets, U., \& Rostovtseva, M. (2015). Developing supportive learning environments. Psychology Research, 5(1), 32-41. David Publishing.

Läänemets, U. (2013, 2017). Didactica minima. (In Estonian). Tallinn: Juura.

Läänemets, U., Kalamees-Ruubel, K., Kiilu, K., \& Sepp, A. (2018). Curriculum Development Considering Formal, Non-formal and Informal Education. In Society. Integration. Education. Proceedings of the International Scientific Conference, II, 286-295.

Meador, D. (2019). Basic Strategies for Providing Structure in the Classroom. Retrieved from thoughtco.com/strategies-for-structure-in-the-classroom-4169394

Ruuska, H. (2015). Opettajan ei tarvitse tehdä työvälineitään. In H. Ruuska, M. Löytönen \& A. Rutanen (Eds.), Laatua! Oppimateriaalit muuttuvassa tietoympäristössä, (pp. 41-46). Porvoo: Bookwell Oy.

Salomon, G. (2006). The systemic vs. analytic study of complex learning environments. In J. Ellen and R.E. Clark (Eds.). Handling Complexity in Learning Environments: Theory and Research, (pp. 255-274). Amsterdam: Elsevier.

Tuomi, J., \& Sarajärvi, A. (2009). Laadullinen tutkimus ja sisällönanalyysi (5th ed.). Helsinki: Tammi.

Vanha, L. (2017). Teachers' perspectives on the role of textbooks in English language learning and teaching in Finland. Master thesis. Faculty of Humanities, University of Oulu. Retrieved from http://jultika.oulu.fi/files/nbnfioulu-201706012364.pdf

Vuorinen, K. (2015). Kieltenoppimateriaalit. In H. Ruuska, M. Löytönen \& A. Rutanen (Eds.). Laatua! Oppimateriaalit muuttuvassa tietoympäristössä, (pp. 117-128). Porvoo: Bookwell Oy.

Wilson, B. (1995). Metaphors for instruction: Why we talk about learning environments. Educational Technology, 35(5), 25-30. Retrieved from http://carbon.ucdenver.edu/bwilson/wils95

Zandvliet, D.B., \& Fraser, B. (Eds.) (2019). Thirty Years of Learning Environments. Looking Back and Looking Forward. Series: Advances in Learning Environment Research, 11. Leiden, The Netherlands: Koninklijke Brill NV. 